\title{
ESSAY
}

\section{Speculating in History}

\author{
N. Connolly \\ Johns Hopkins University, US \\ nconnol2@jhu.edu
}

Nathan Connolly reflects on the convening of Black intellectuals in Miami in April 2018 and the nature of speculation.

Keywords: Miami school; Miramar; speculation; institutional diversity; manufactured scarcity

I love that Donette brought this group together. But I'm sad, too. Today feels too much like a special occasion. For a long time, I've worried that Miami's black intellectual diaspora remains mostly a scattered group. It feels cast about. A little here, a little there.

Imagine, if there was a "Miami School" - an intellectual collective that might consider and institutionalize the kinds of questions that being black in Miami has historically raised. Right off the top, I see the black experience here as an affirmation of a classic Miami paradox-that this place is both singular-exceptionaland yet, given the people here, just like some other place from which we or our forbearers came. Miami's the special-that-ain't-that-special.

Here as well as anywhere else, moments of displacement, relocation, migration, and incarceration feed practices of political imagining. These stand not, and ought not stand, separate from our scholarly imaginings. But it's incumbent on us to ask the questions. What does, say, the history of Krome Detention Center, Little Haiti, Liberty City, or Overtown have to teach us about the ways we should govern, the ways we should write, or build our various learning or political collectives? What does it mean to live under multicultural forms of white supremacy, indeed to understand multiculturalism as white supremacy?

These, I'll admit, have been my preoccupations over the last fifteen years. But, as writers and artists, the "Miami" in each of us generates some set of interests rooted in the overlapping intellectual and political worlds of North America, South America, and the Caribbean. What if Miami became, through our efforts, a laboratory for institutionalizing academically new political movements, for applying civically new scholarly innovations? What kinds of real-world happenings can be born of our experiences and research questions? What's the transformative potential of the "Miami" in our intellectual personalities?

I'm merely speculating, of course. But how different might our respective disciplines be, how different might our hometown be, if rather than real estate developers, international bankers, and various empire builders, we did the speculating for a change?

Speculation really is the story of our hometown, isn't it? We've certainly paid a high price for it. The lesser angels of capitalism have made this, in great measure, a town of serial booms and busts. The Great Depression hit here three years before it reached most everywhere else. The subprime crisis? We did that first here, too. Well in advance of the downturn of 2008-09, activist organizations, like Max Rameau's "Take Back the Land," tried to shed light on the foreclosure and affordable housing crisis. In 2004, the Brookings Institution named Miami the poorest major city in America. Ten years later, it was still in the top three cities (or bottom three) for widest income inequality and lowest gross income (Berube).

If that weren't bad enough, I fear, too, that, to some discernible degree, the same forces of speculation that have left our city so racked by poverty and inequality have played a role in our respective choices to leave it. I fear our careers and various professional fortunes remain tightly bound to speculative capitalism, and to the ultimate detriment of...this...place.

But let me not get too dark on this happy occasion. Allow me instead to share a few lessons I've learned from my time in and work on Miami. I can't promise they'll inspire the founding of a "Miami School," as 
such. I hope, though, that they'll at least help us consider our shared predicament and our shared future as a diaspora of the Diaspora.

The First Lesson: even across Miami's more sordid history, speculation can, at times, have affirming meanings for subaltern people. We are the people (or the progeny of a people) who made emotional and actual investments in a place, on some earlier day, they (we) hardly knew. For even the most meager people, "making home" represents a calculated risk. It's an act of speculation. And, risk be damned, people built. Indeed, build we still must.

One could argue, too, that, we, the black children of Miami, have made at least one other investment, just as speculative, in this here world of letters. While still a graduate student, I was told more than once by well-meaning white urban historians that our city didn't have enough-archivally-to sustain a proper book-length treatment. I learned, though, that if you cross a few residential color lines and violate a few disciplinary boundaries (a little field work, more-than-a-little archival work, sprinkled, perhaps, with some Black Power analytics), Miami can absolutely be a valuable place to think with. You may even get a book out of it.

Each of us, I know, has some variation of this story. There's some way in which we needed to creatively speculate-often against great institutional countermeasures-just to have a career in writing, art. The disciplines in which we've made our homes were, during an earlier day, curated by white and mostly male scholars, most with the specific aim to forget the true color of their intellectual debts. And in many ways, that racist and sexist curation continues.

Given oppressive power as a precondition of our creative careers, our academic fields continue to promise little more than spiritual hazards, and sometimes, especially for women scholars, far worse. The White Academy of today and the intrepid, ancient black academics who preceded us offer us no assurances that anyone will or should even read our work. They guarantee no existential safety at all. And yet we do this anyway.

Now, I don't mean to liken college professors-even professors of color-to some group of hardy entrepreneurs in the wilderness. I merely wish to point out the speculative nature of even this ostensibly safest of professions. I wish to point out, further, that because of our kind of "black," successful speculation stands as so rare a thing in the world, and we have become the unwitting targets of other's speculative designs.

Consider this as a Second Lesson. Quicker than some of us can properly pronounce "Michel Foucault," we get pulled out of here by graduate programs and academic institutions rich enough to splurge some on "diversity." We think we're leaving on our own volition, that we're just that damn good. And we are, indeed, good...and beautiful. Look at us! But black intellectuals have also always been.

What's changed? The institutions. In 1978, 2003, and again 2015, the U.S. Supreme Court issued a series of decisions that institutionalized affirmative action and defined "diversity" as having nothing at all to do with undoing past forms of discrimination. The point, rather, was merely to incorporate "difference" as a way to create learning environments, in one Justice's words, that were "livelier, more spirited, and simply more enlightening and interesting" (Grutter v. Bollinger, 539 U.S. 306, 2003). The ensuing diversity industry has spurred universities to compete with each other, acquiring, sometimes even concentrating, talented artists and intellectuals of color. It's a kind of hobby. Which major research corporation has collected the richest cabinet of curiosities?

In time we learn to tug on the paymaster's speculative impulses. Our job is to get paid. Their job is to have just enough blue-chip difference lying around to improve the brand, without, of course, having an adverse effect on how the place actually runs. Understand that that's the racism of multiculturalism. And understand that it's now our job to change it.

As most of you now know, I'm a Miami imposter. I watched a lot of Miami Vice from my house in Miramar, and I went to St. Thomas University in what's now called Miami Gardens. But it wasn't until we needed a DJ for a party we were throwing on campus that I first ventured into Liberty City on my own. Me and my boy Louis, a Haitian from Boston, went to DJ Uncle Al's house. Dudes were in there broadcasting with a damn milk crate as a stool. Pared down doesn't even get it. But Al and his team came back to St. Thomas, threw the banging-est party in university history, and left me-just there, perplexed, about there being whole corners of the city I never knew existed. That's when I first saw segregation in our little global city.

Being from here, we should be real woke about the diversity bullshit. Red, white, black, and brown, we call this so-called capital of the Caribbean home, but, Lord, if Miami's "Diversity" ain't been one of the biggest bait-and-switches in our sun-drenched history of selling points, swindles, and snake-oil. With respect to our efforts as scholars and artists, it's important to be honest: there is no outside to capitalism. (We paid Al in cash from the door). But that doesn't foreclose the prospect of recasting "diversity" as anti-racism, nor does it prevent us from pursuing and perfecting our work. 
The challenge is to create without becoming a fetish. And we cannot do that as lone, individuals negotiating with the paymasters and speculators of foundations and corporate universities. Organizing still stands as one of the greatest protections.

Our predicament strikes me as not all that different that of another black Miamian-Purvis Young. Young, you may know or recall, was an artist-a painter-from Overtown. After a three-year stint in prison in the late 1960s, Young took to painting. His release coincided with the demolition of Miami's old Central Negro District. Between odd jobs, he picked up debris from the side of the road, rummaged through abandoned buildings, repurposed old telephone bills, refrigerator doors, and cardboard, and painted them.

"It was mostly white people interested [in my work]," Young remembered. "Some people would say stuff, say I looked like Gauguin, all different artists...A lot of black people seen them but they didn't say much to me about it. Some of them said I was mad. Some cursed me out. Some liked it. Some of them admired me. Some didn't. A friend of mine...say to me: 'I just look at your paintings but I don't see nothing. But every time I turn around, you're in the newspaper"' ("This is Life" 393).

Young became a sensation in elite modern art circles in the 1990s. And one of the first things he wanted to do when he began to sell his work was, actually, to stop painting on repurposed trash. He wanted to buy canvas, to pursue what he considered by his own measure painting's higher forms. But buyers made it clear they would not support his canvas work. By their estimation, he had to continue painting the debris of Miami's urban crisis. In addition to that, his technical roughness earned his work labels like "real," "raw," "urban," and, of course, "black." With newfound legitimacy from the elite arts scene, Young's work began selling for as much a $\$ 35,000$ a piece.

Speculation continued apace, in both art and real estate. In 1993, Don and Mera Rubell bought an old 45,000-square-foot Drug Enforcement Agency warehouse in Wynwood, sparking gentrification in that neighborhood. In short order, they bought some 3,000 pieces of Purvis's work to house there. Local Miami lore swirled up around tales of Purvis's painted Overtown, with this or that art maven willing to pay top dollar for a piece. Apparently, one French billionaire, Gerárd Louis Dreyfus, offered Young between $\$ 3$ million and $\$ 5$ million for his entire body of work. The only condition was that Purvis destroy $2 / 3$ of everything he'd ever done. High-price art, required scarcity, after all. Young's response, for those interested in such things: "Those people who say I paint too much don't say that birds fly too much, Shakespeare wrote too much, or opera singers sing too much. But it don't bother me that they say I paint too much; I just paint what I see and feel" (Paintings).

We should beware of the recurrence and utility of manufactured scarcity. True in real estate; true in arts and letters. Large buyers in the world of art promise exposure. They lean on artists for a bulk discount. They hold pieces in reserve to drive up value. Large buyers in the world of letters-our universities-do much of the same. They promise exposure and tenure for a bulk discount on our creative and administrative work. They turn our labors toward manning the bureaucracy and serving white dominated presses, universities, and committees. They hold us in reserve-call it "service"-and drive up the prices of our own talents. Ultimately, our abilities become broadly unaffordable to poorer communities, often the very communities from which we come, those that likely need our expertise the most.

Before Purvis Young's life and career had ended, he'd been swindled by managers who'd locked him in his studio and taken over his bank accounts. His most affluent buyers had taken to panic-selling their various Purvis Young collections, usually for $40 \%-50 \%-60 \%$ discounts. The speculative bubble around this single black artist burst, and the "real" and "raw" creations that once conferred great status on the captains of Modern Art now bloat the warehouses of online wholesalers. With a few pieces in storage at the American Folk Art Museum and the Smithsonian, they're today more archival than anything else-evidence of what was.

The parable of Purvis Young brings me to my concluding lesson, scholar-artist: Organize! Grassroots cultural production needs infrastructural protection. For as tragic as Young's story is (and it is), for every Purvis Young there are thousands of other artists, most of whom women, whose art-work remains relegated to the margins. As the Miami anthropologist Lara Stein Pardo explains, the structural and demographic hazards facing artists, the arts, and women creatives in particular, exhibit Miami's uniquely Caribbean predicament, a "brain-drain" where the talented people leave. Well many, perhaps even most, but certainly not all.

Individually, many of us have turned stifling intellectual frustrations into great research questions and great art. We've variously tried in ad hoc fashion to enrich our workplaces, maybe occasionally our communities. But, as has long been true, big speculators edge out and feast upon, us, the little ones. We therefore ought not to let the temporary condition of our respective professional exceptionalism prevent us from organizing and institutionalizing what remains merely, at present, scholarly critique. We should take today 
and the conversations to come as an opportunity to weaponize our knowledge of this city, our knowledge of racial and gender power. We can flip our encounters with the "diversity" industry to demand redress for the processes of discrimination that produced difference in the first place. We may never get around to establishing The Miami School, at least not this weekend. But, under our powers, the eventual consequences could be HUGE. But that's just me speculating.

\section{Competing Interests}

The author has no competing interests to declare.

\section{References}

Berube, Alan. "All Cities are Not Created Equal." Brookings Institution, February 20, 2014, www.brookings. edu/research/all-cities-are-not-created-unequal/.

Grutter v. Bollinger, 539 U.S. 306, (2003).

Pardo, Lara Stein. "Artists, Aesthetics, and Migrations: Contemporary Visual Arts and Caribbean Diaspora in Miami, Florida." 2013. University of Michigan, PhD Dissertation.

Young, Purvis. Purvis Young: Paintings from the Street. Exhibition catalog, 2006.

Young, Purvis. "This is Life." Souls Grown Deep: Once that River Starts to Flow, edited by Paul Arnett and William Arnett. Tinwood Books, 2000, pp. 392-427.

How to cite this article: Connolly, N 2020 Speculating in History. Anthurium, 16(1): 9, 1-4. DOI: https://doi. org/10.33596/anth.364

Published: 31 March 2020

Copyright: (c) 2020 The Author(s). This is an open-access article distributed under the terms of the Creative Commons Attribution 4.0 International License (CC-BY 4.0), which permits unrestricted use, distribution, and reproduction in any medium, provided the original author and source are credited. See http://creativecommons.org/licenses/by/4.0/. 